\title{
Thermochemical processing of a South African ultrafine coal fly ash using ammonium sulphate as extracting agent for aluminium extraction
}

Frédéric J. Doucet ${ }^{\mathrm{a},{ }^{,}}$, Sameera Mohamed $^{\mathrm{a}, \mathrm{b}}$, Nicole Neyt ${ }^{\mathrm{b}}$, Barbara A. Castleman ${ }^{\mathrm{b}}$, Elizabet M. van der Merwe $^{\text {b,* }}$

${ }^{\text {a }}$ Council for Geoscience, 280 Pretoria Street, Silverton, Pretoria 0001, South Africa

${ }^{b}$ Department of Chemistry, University of Pretoria, Lynnwood Road, Pretoria 0002, South Africa

"Co-corresponding authors: fdoucet@geoscience.org.za (+27 12841 1300); liezel.vandermerwe@up.ac.za (+27 12420 5379)

\section{Highlights}

- Aluminium was extracted from an ultrafine coal fly ash

- Extraction was achieved via thermochemical treatment followed by aqueous leaching

- The process used ammonium sulphate, a low-cost, recyclable extracting agent

- Extraction efficiencies amounted to $95.0 \%$ of aluminium from the amorphous phase

- Silicon from quartz, mullite and the amorphous phase was not extracted

\begin{abstract}
South African coal fly ash represents an untapped secondary resource of aluminium. Continuous research is conducted to develop suitable chemical and/or geometallurgical processes for aluminium extraction, preferably accompanied by minimal silicon extraction. The thermochemical treatment of a South African ultrafine coal fly ash was investigated to test the feasibility of recovering aluminium using ammonium sulphate, a widely available, low-cost, recyclable chemical agent. The optimum processing conditions were determined to be a temperature of $500^{\circ} \mathrm{C}$ and a fly ash to ammonium sulphate weight ratio of 2:6 when a reaction time of $1 \mathrm{~h}$ was used. Water leaching of the reaction product obtained under these conditions resulted in the selective recovery of $95.0 \%$ aluminium from the amorphous phase, with less than $0.6 \% \mathrm{Si}$ extracted. Mullite was unlikely to have reacted with the extracting agent. Except for Si, the process was not element-selective, but the extraction of iron could be minimized by increasing the
\end{abstract}


treatment temperature to $600^{\circ} \mathrm{C}$ without compromising Al extraction. Thermochemical treatment using ammonium sulphate may therefore represent a promising technology for extracting aluminium from coal fly ash, which could be subsequently converted to value-added products such as alumina.

Keywords: Coal fly ash; Thermochemical processing; Aluminium extraction; Ammonium sulphate

\section{Introduction}

Coal fly ash (CFA) is a solid incombustible residue that is mainly produced during the combustion of pulverized coal in thermoelectric power stations. Eskom, the main power generator in South Africa, consumed 124.7 Mt of coal producing 36.2 Mt of CFA in 2011 [1]. Only about 5\% of CFA is currently recycled, mostly in the form of building materials such as bricks and as a cement extender, while the unused CFA is disposed of either in dry or slurry form in ash-handling dams which require maintenance and eventual rehabilitation. SASOL Synfuels generates an additional 4 million tons per annum [2].

Aluminium is typically the second most abundant element in CFA after silicon, which makes CFA a potential pre-mined substitute of bauxite for alumina production. This is of particular relevance to South Africa which has no mineable bauxite ore deposits, the raw material used to produce aluminium. The chemical extraction of aluminium from CFA has been well documented over the past 50 or so years, and the topic remains high on the R\&D agenda [3-7]. It is generally performed using metallurgical methods, which can be categorized into three types of processes: (i) acid leaching, (ii) sintering, and (iii) HiChlor [8]. All the processes have their own advantages and drawbacks. Some of the processes are nevertheless in the early stages of commercialization, although they might not be currently economically viable in their own right. For this reason, researchers and companies are increasingly looking into aluminium recovery combined to potential additional revenue streams generated from the simultaneous recovery of other strategically-valuable elements [9].

Although South Africa has been actively involved in research and development for CFA beneficiation and/or utilization $[2,10-16]$, research on the recovery of aluminium from South African CFA $[5,17-19]$ is limited. It is also mostly restricted to acid leaching methods, which are unlikely to be adopted at large scale. The focus of our group was to identify and test a promising aluminium extraction process that 
makes use of a widely available, low-cost, recyclable extracting agent. Ammonium sulphate salt $\left(\left(\mathrm{NH}_{4}\right)_{2} \mathrm{SO}_{4}\right)$ meets all three criteria [20], and its thermal solid-solid reactions with silicate and oxide minerals for elemental extraction have been extensively studied [21-26]. Its reaction with CFA has also recently emerged as an area of great interest in China, owing to its advantages over acidic, alkali, and acid-alkali methods [27-29]. Al extraction efficiencies greater than $85 \%$ were obtained from Chinese CFA, with Al being extracted from both the amorphous phase and the mullite component of CFA.

The primary objective of this paper was to demonstrate the usefulness of thermochemical solid-solid treatment of a South African classified CFA with $\left(\mathrm{NH}_{4}\right)_{2} \mathrm{SO}_{4}$, coupled to aqueous dissolution, for the selective extraction of aluminium from the amorphous glass phase. A secondary objective was to test the selectivity of $\left(\mathrm{NH}_{4}\right)_{2} \mathrm{SO}_{4}$ for the preferential extraction of aluminium over silicon, since the latter is undesirable for high-purity alumina synthesis.

\section{Experimental}

\subsection{Materials description, preparation and characterisation}

A representative sample of a classified, ultrafine Class-F coal fly ash (CFA) was obtained from the Ash Resources Pty Ltd.'s ash beneficiation site at Eskom's Lethabo Thermal Power station, which is located between Vereeniging and Sasolburg in the Free State province of South Africa. This commercial-grade CFA is air-classified on site and is specified to have a mean particle size between 3.9 and $5.0 \mu \mathrm{m}$, with more than $90 \%$ of the volume distribution of its particles having a diameter smaller than $11 \mu \mathrm{m}$. After classification it is marketed as a very fine, spherical, pozzolanic, and highly reactive aluminosilicate with low carbon content. The product currently finds application in the construction industry, but is also used in small quantities in the rubber and polymer industries.

Homogeneous sub-samples of the prepared batches were obtained with a sample splitter for future experiments. Particle size distribution (PSD) was obtained by laser diffraction (Malvern Mastersizer, 2000 fitted with a Hydro 2000G dispersion unit, Malvern Instrument Ltd. Worcester, UK) to confirm the fineness of the ash particles. Scattered light data were recorded from 2000 to 5000 snapshots of $10 \mu \mathrm{s}$. A polydisperse mode of analysis and a refractive index of 1.533 with an adsorption of 0.1 were chosen. Size data collection was performed at constant obscuration in the range $15-20 \%$. 
The elemental and mineralogical compositions of the ash were analysed using XRF (ARL9400XP+ XRF spectrometer, Thermo ARL, Switzerland)) and XRD (PANanalytical X'Pert PRO X-ray diffractometer), respectively. Detailed description of these analyses was given elsewhere [30].

A Zeiss Ultra SS field emission scanning electron microscope (FESEM), operated at an acceleration voltage of $1 \mathrm{kV}$, was used under dry high-vacuum condition to observe differences in morphology of the CFA particles before and after treatment. For this purpose, the powder was mounted on a double-sided carbon tape by dipping carbon stubs into the samples. Excess material was removed by gentle blowing with compressed nitrogen. The sample was then sputter-coated with carbon in an Emitech K550X (Ashford, England).

Ammonium sulphate (reagent grade, $99.5 \%$, Merck, South Africa), $\left(\mathrm{NH}_{4}\right)_{2} \mathrm{SO}_{4}$, was used as supplied in all experiments.

\subsection{Methods and processes}

\subsubsection{Thermochemical processing of coal fly ash}

The first step of the staged process involved the processing of CFA by thermochemical treatment using $\left(\mathrm{NH}_{4}\right)_{2} \mathrm{SO}_{4}$ as extracting agent. $\left(\mathrm{NH}_{4}\right)_{2} \mathrm{SO}_{4}$ is widely available at low-cost and offers the added advantage of being recyclable [20], in comparison to other activating agents such as $\mathrm{NaOH}$ and $\mathrm{Na}_{2} \mathrm{CO}_{3}$. Insight on the thermal decomposition of pure $\left(\mathrm{NH}_{4}\right)_{2} \mathrm{SO}_{4}$ over the temperature range studied was provided elsewhere [26]. CFA and $\left(\mathrm{NH}_{4}\right)_{2} \mathrm{SO}_{4}$ salt were thoroughly mixed at two mass ratios $(2: 3$ and 2:6 m/m) in a fused quartz crucible. It was important to use a CFA: $\left(\mathrm{NH}_{4}\right)_{2} \mathrm{SO}_{4}$ mass ratio which gave a slight excess of $\mathrm{SO}_{4}$ over $\mathrm{Al}$ (mole:mole), so that the amount of $\left(\mathrm{NH}_{4}\right)_{2} \mathrm{SO}_{4}$ did not represent a limiting factor for $\mathrm{Al}$ extraction. The $2: 3$ and 2:6 m/m ratios of $\mathrm{CFA}:\left(\mathrm{NH}_{4}\right)_{2} \mathrm{SO}_{4}$ were equivalent to $\mathrm{SO}_{4}: \mathrm{Al}$ mole ratios of 1.73 $\left(\mathrm{SO}_{4}\right.$ in slight excess over $\left.\mathrm{Al}\right)$ and $3.47\left(\mathrm{SO}_{4}\right.$ in large excess over $\mathrm{Al}$, to circumvent the fact that some $\mathrm{SO}_{4}$ reacts with other elements contained in CFA (e.g. Ca, Fe, Ti)) respectively. The mixtures were subsequently inserted in a static muffle furnace operating at different reaction temperatures $(400,500$ and $600^{\circ} \mathrm{C}$ ) for $1 \mathrm{~h}$. The products of the reactions, which either had the appearance of sintered solid or were free-flowing powders (depending on the reaction temperature) were then subjected to a dissolution procedure for Al extraction. 


\subsubsection{Dissolution experiments}

Chemical extraction of $\mathrm{Al}$ and other major elements from untreated and thermochemically-treated CFA was investigated in ultrapure water $(3 \mathrm{~g} / 300 \mathrm{ml})$ at $22^{\circ} \mathrm{C}$. All treatment solutions were continuously stirred to maintain treated CFA particles in suspension throughout the experiment. The $\mathrm{pH}$, electrical conductivity and temperature of the suspension were logged using a Hanna HI 2829 multiparameter logger at $30 \mathrm{~s}$ intervals to collect time-series data on the dynamics of the system. The reaction was terminated when the $\mathrm{pH}$ and electrical conductivity remained unchanged for 10-15 min. At completion of the dissolution experiment, the leachate was filtered under reduced pressure through $0.4 \mu \mathrm{m}$ membranes filters (Whatman Nucleopore ${ }^{\circledR}$ Track-Etched polycarbonate, Whatman UK Ltd.) in closed polycarbonate filtration vessels (Sterifil, $47 \mathrm{~mm}$ Millipore). The concentrations of dissolved $\mathrm{Al}$ and other elements were determined by ICP-OES at an accredited laboratory (Waterlab Pty Ltd, Pretoria, South Africa). These ICP data were used to calculate elemental extraction efficiencies, i.e. the mass fraction of elements extracted as sulphates from the mass of these elements present in CFA, by combining them to the XRF data of untreated CFA (for aluminium, iron, calcium and titanium), and the estimated aluminium content of the mullite and amorphous phases (in the case of Al) in untreated CFA. The non-dissolved residues $\left(\mathrm{CFA}_{\text {res }}\right)$ were rinsed thoroughly with ultra-pure water, oven-dried at $40^{\circ} \mathrm{C}$ up to constant weight. Their chemical and mineralogical compositions were also determined by XRF and XRD respectively.

\section{Results and discussion}

\subsection{Materials characterization}

A detailed surface and bulk characterization of the classified, ultrafine Class- $F$ coal fly ash (CFA) used in this study was performed and was reported elsewhere [30]. Briefly, the XRD pattern of CFA (Figure 1) demonstrated that the sample was predominantly composed of an amorphous alumina silica glass phase (62.1\%), which co-existed with the two primary crystalline phases, mullite $\left(\mathrm{Al}_{6} \mathrm{Si}_{2} \mathrm{O}_{13} ; 31.8 \%\right)$ and quartz $\left(\mathrm{SiO}_{2} ; 6.1 \%\right)$. This mineralogy was confirmed by the XRF data, which indicated the presence of six major chemical constituents $\left(\mathrm{SiO}_{2}, 49.3 \% ; \mathrm{Al}_{2} \mathrm{O}_{3}, 34.0 \% ; \mathrm{Fe}_{2} \mathrm{O}_{3}, 5.8 \% ; \mathrm{CaO}, 5.1 \%\right.$; $\left.\mathrm{TiO}_{2}, 2.0 \% ; \mathrm{MgO}, 1.0 \%\right)$. Additional features of the sample included a low total alkaline content $\left(\mathrm{Na}_{2} \mathrm{O}+\mathrm{K}_{2} \mathrm{O}<1 \%\right)$, a low total concentration of alkaline earth metals ( $\mathrm{CaO}+\mathrm{MgO}<6 \%$ ), and a low loss on ignition ( $\mathrm{LOI}$ of $0.52 \%)$. The latter indicated a low percentage of moisture, sulphur, unburned carbon, carbonates and hydroxides. 


\subsection{Structural changes during thermochemical treatment of coal fly ash}

Characterization of thermochemically-treated CFA using XRD, and FE-SEM was carried out in order to better understand the effect of $\left(\mathrm{NH}_{4}\right)_{2} \mathrm{SO}_{4}$ on CFA.

\subsubsection{Mineralogical characterization}

Figure 1 and Tables 1 to 3 report the crystalline phases present in CFA thermochemically-treated at $600^{\circ} \mathrm{C}, 500^{\circ} \mathrm{C}$ and $400^{\circ} \mathrm{C}$ respectively, where their amounts were normalized to $100 \%$. The reasons for presenting normalized crystalline mineral contents were two-fold. First, the amorphous content of untreated and thermochemically-treated CFA remained constant at about $62 \pm 1 \%$ relative to the total mineralogical composition, which made it appropriate to compare normalized values of crystalline phases between samples obtained under varying experimental conditions. Second, since the amorphous content represented the same significant proportion of the total mineralogy for all samples, the normalized approach permitted to highlight the occurrence of new sulphate-bearing minerals present in minor amounts, but which were nevertheless important to stress since they represented several percents of the total crystallinity of generated samples (e.g. comparative content of millosevichite between Tables 2 and 3). For comparison purpose, the crystalline phases of untreated fly ash are also reported, and consisted of mullite (84.3\%), quartz (15.5\%) and a very small amount of lime $(0.2 \%)$. Lime was very reactive and was not identified in any treated CFA samples, whereas mullite and quartz coexisted in all samples, albeit representing a much smaller proportion of crystalline minerals (15-45\% for $500^{\circ} \mathrm{C}$ and $600^{\circ} \mathrm{C}$ ) than in untreated CFA (99.8\%) (Tables 1-3). 

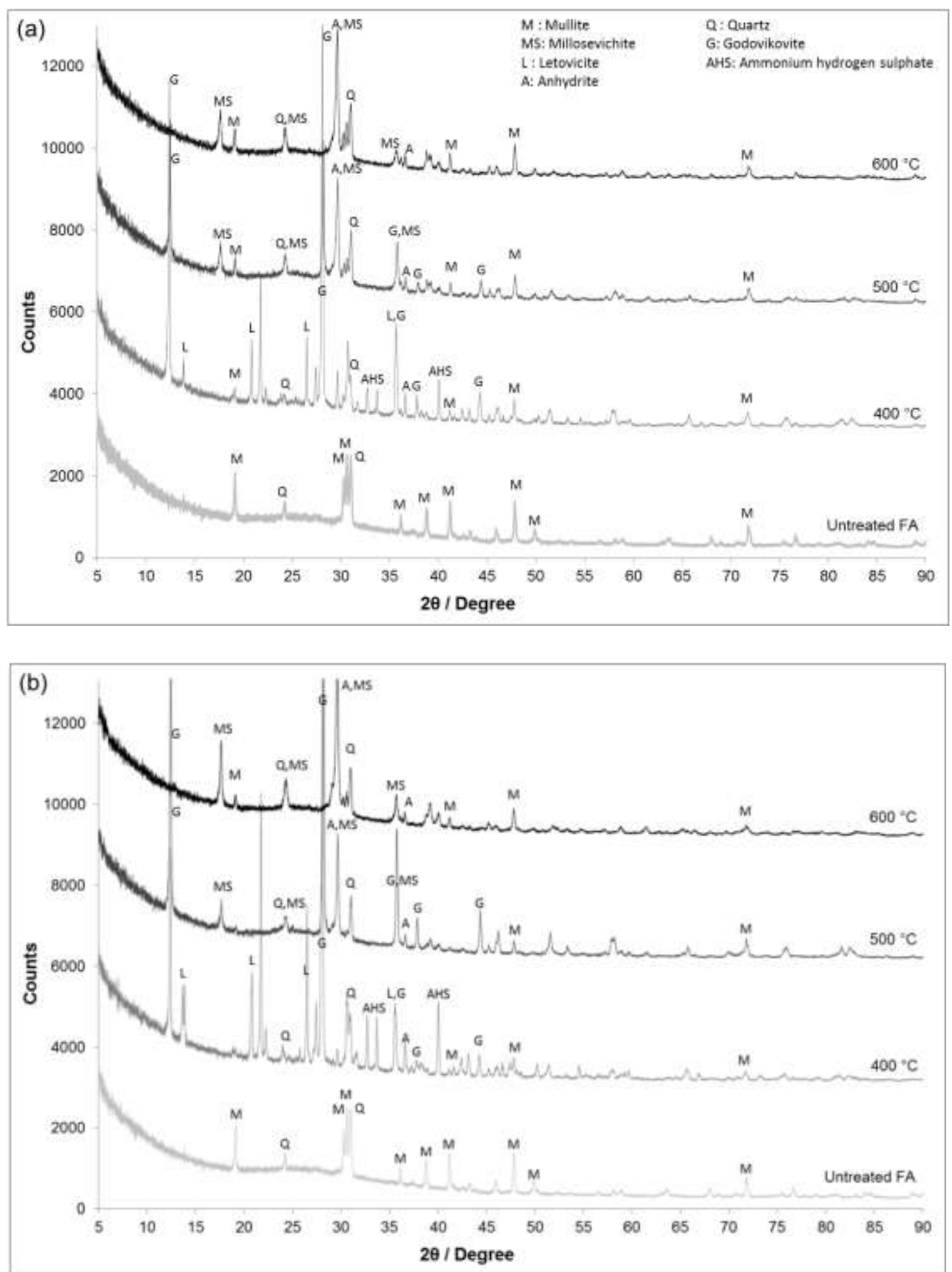

Figure 1 XRD analysis of untreated fly ash and fly ash thermochemically-treated at $400^{\circ} \mathrm{C}, 500^{\circ} \mathrm{C}$ and $600^{\circ} \mathrm{C}$ for $1 \mathrm{~h}$ using a CFA: $\left(\mathrm{NH}_{4}\right)_{2} \mathrm{SO}_{4}$ ratio of (a) 2:3 and (b) 2:6. 
CFA processed at $600^{\circ} \mathrm{C}$ exhibited the least complicated XRD patterns and quantification of the crystalline phases was possible (Table 1). 100\% of extracted Al crystallised in the form of water-soluble anhydrous aluminium sulphate $\left(\mathrm{Al}_{2}\left(\mathrm{SO}_{4}\right)_{3}\right)$, also called millosevichite, which represented $46 \%$ and $67 \%$ of thermochemically-processed CFA for CFA: $\left(\mathrm{NH}_{4}\right)_{2} \mathrm{SO}_{4}$ ratios of 2:3 and 2:6 respectively. The dissolution of formed $\mathrm{Al}_{2}\left(\mathrm{SO}_{4}\right)_{3}$ during the leaching step explains the measured acidity of the leachate solutions (Figure 2A). Calcium ( $\mathrm{Ca}$ ) was also extracted in significant amount, and crystallised in the form of anhydrous calcium sulphate $\left(\mathrm{CaSO}_{4}\right)$, also called anhydrite (7-9\%). Since very little Ca was present in mineral forms in untreated CFA (only lime had been detected), it can be argued that most of the reacted Ca originated from the amorphous phase. Metals present in the glassy phase had therefore been very reactive at this temperature. This strongly suggested that most, if not all, $\mathrm{Al}$ which had been converted to $\mathrm{Al}_{2}\left(\mathrm{SO}_{4}\right)_{3}$ also originated from the amorphous phase. At this point, there is no evidence that mullite had reacted to any great extent with the chemical additive under the experimental conditions tested in this study. In principle, the change in the mullite:quartz ratio in CFA after thermochemical treatment (Tables 1 to 3 ) could have been an indication of the reactivity of mullite during thermochemical treatment. However, this reasoning does not apply, since the XRD data reported were not quantitative. Untreated CFA was micronized before XRD data collection and was characterized by particles smaller than $10 \mu \mathrm{m}$. However, thermochemically-treated CFA samples were not micronized since they contained water-soluble sulphate-based species whose reactivity with ethanol used during micronisation was unknown, and were therefore simply ground with a pestle and mortar. As a result, the sizes of particles contained in the different samples (untreated and treated CFA) were very different, with treated CFA being composed of coarser particles than untreated CFA. This would have caused artefacts during XRD data collection, such as preferential orientation, a problem especially well-recognised with quartz. Increasing thermochemical reaction time and adjusting CFA: $\left(\mathrm{NH}_{4}\right)_{2} \mathrm{SO}_{4}$ ratio may promote mullite reactivity, as observed for Chinese CFA [28-29], although this may not apply to South African CFA. Mullite crystals can be seen as inclusions within the CFA glassy matrix, and therefore some degree of reactivity of this matrix with $\left(\mathrm{NH}_{4}\right)_{2} \mathrm{SO}_{4}$ is paramount to permit direct contact between the extracting agent and mullite, which would then allow the reaction to occur. Our study demonstrated that little $\mathrm{Si}(\leq 0.6 \%)$ had been extracted, which indicated the absence of reactivity between the Si-O bonds in the glassy matrix of the tested CFA and $\left(\mathrm{NH}_{4}\right)_{2} \mathrm{SO}_{4}$. The reporting of $\mathrm{Si}$ extraction data for Chinese CFA is necessary for comparison between matrix reactivity for ashes from different sources. 

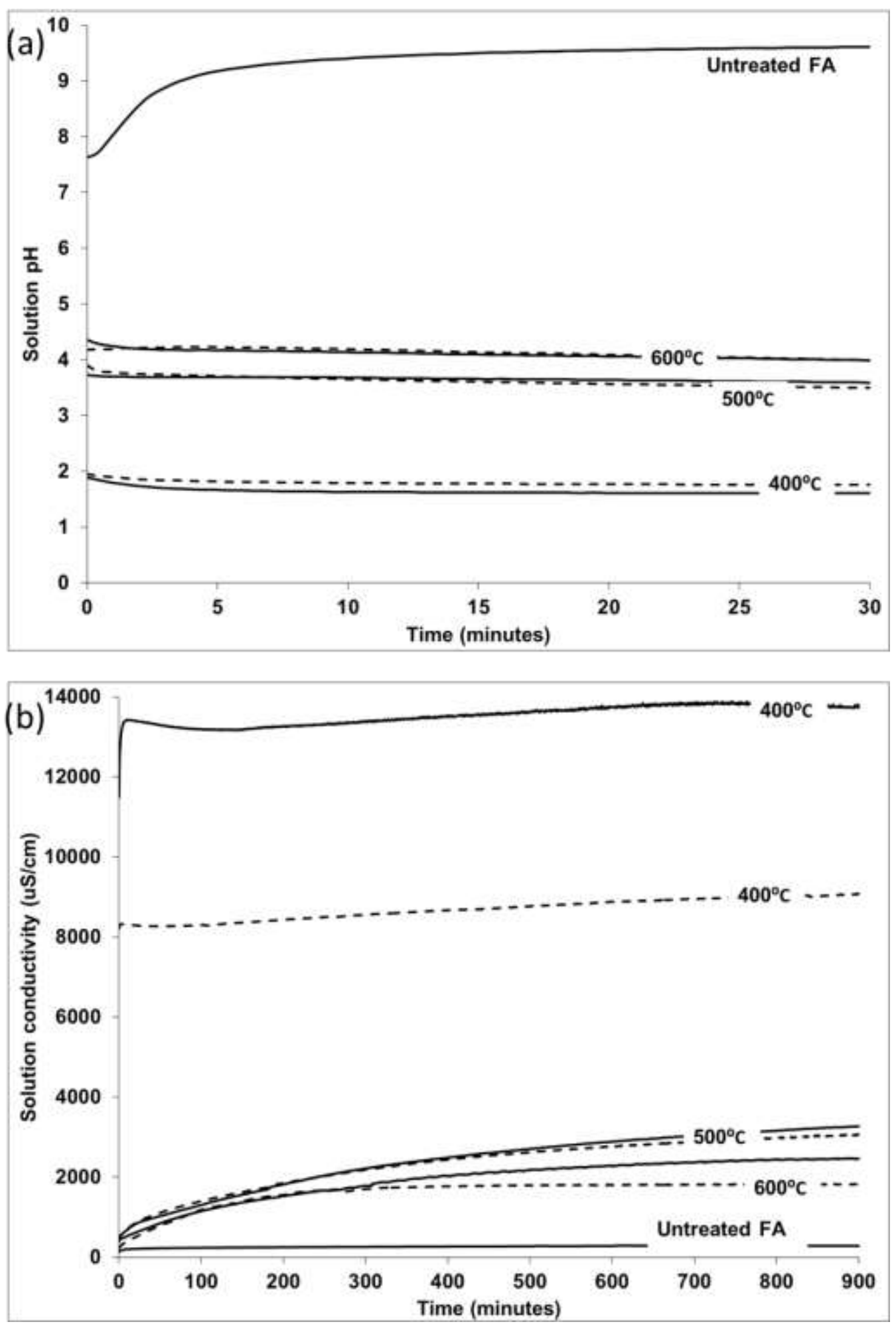

Figure 2 Solution $\mathrm{pH}$ (a) and conductivity (b) profiles for the leaching of untreated and thermochemically-treated South African ultrafine coal fly ash (Chemical agent used: $\left(\mathrm{NH}_{4}\right)_{2} \mathrm{SO}_{4}$; Thermochemical treatment performed at $400^{\circ} \mathrm{C}, 500^{\circ} \mathrm{C}$ and $600^{\circ} \mathrm{C}$ for $1 \mathrm{~h}$; CFA: $\left(\mathrm{NH}_{4}\right)_{2} \mathrm{SO}_{4}$ ratio of 2:3 (dashed line) and 2:6 (plain line)) in ultrapure water at ambient temperature. 
Table 1 Rietveld quantitative phase analysis of untreated fly ash and fly ash thermochemically-treated at CFA: $\left(\mathrm{NH}_{4}\right)_{2} \mathrm{SO}_{4}$ ratios of $2: 3$ and 2:6 and at a temperature of $600^{\circ} \mathrm{C}$ (Reaction time: $1 \mathrm{~h}$; Chemical agent used: $\left(\mathrm{NH}_{4}\right)_{2} \mathrm{SO}_{4}$; only the crystalline phases are reported and were normalized to $100 \%)$.

\begin{tabular}{|c|c|c|c|c|}
\hline Minerals & Chemical formula & $\begin{array}{c}\text { Untreated } \\
\text { fly ash }\end{array}$ & $\begin{array}{c}\text { CFA: }\left(\mathrm{NH}_{4}\right)_{2} \mathrm{SO}_{4} \text { ratio } \\
2: 3\end{array}$ & CFA: $\left(\mathrm{NH}_{4}\right)_{2} \mathrm{SO}_{4}$ ratio $2: 6$ \\
\hline Mullite & $\mathrm{Al}_{6} \mathrm{Si}_{2} \mathrm{O}_{13}$ & 84.3 & 33.2 & 16.3 \\
\hline Quartz & $\mathrm{SiO}_{2}$ & 15.5 & 11.4 & 9.8 \\
\hline Lime & $\mathrm{CaO}$ & 0.2 & n.d. & n.d. \\
\hline Anhydrite & $\mathrm{CaSO}_{4}$ & n.d. & 9.3 & 6.9 \\
\hline Millosevichite & $\mathrm{Al}_{2}\left(\mathrm{SO}_{4}\right)_{3}$ & n.d. & 46.1 & 67.0 \\
\hline
\end{tabular}

n.d.: not detected

Although the amounts of Al extracted from CFA processed at $500^{\circ} \mathrm{C}$ and $600^{\circ} \mathrm{C}$ were identical for an CFA: $\left(\mathrm{NH}_{4}\right)_{2} \mathrm{SO}_{4}$ of 2:6 (Figure 3), its speciation was distinctively different. At $500^{\circ} \mathrm{C}, \mathrm{Al}$ from the glass phase had crystallised to form two water-soluble species: $\mathrm{NH}_{4} \mathrm{Al}\left(\mathrm{SO}_{4}\right)_{2}$, also called godovikovite, and $\mathrm{Al}_{2}\left(\mathrm{SO}_{4}\right)_{3}$ (Table 2). The CFA: $\left(\mathrm{NH}_{4}\right)_{2} \mathrm{SO}_{4}$ ratio had a significant effect on the proportion between these two Al species, with a 2:6 ratio favouring the formation of $\mathrm{NH}_{4} \mathrm{Al}\left(\mathrm{SO}_{4}\right)_{2}(46 \%)$ over $\mathrm{Al}_{2}\left(\mathrm{SO}_{4}\right)_{3}(20 \%)$, whereas a $2: 3$ ratio generated the two species in similar amount ( $21 \%$ and $26 \%$ respectively). CFA treated at $500^{\circ} \mathrm{C}$ was also composed of $19-27 \% \mathrm{CaSO}_{4}$, depending on the CFA: $\left(\mathrm{NH}_{4}\right)_{2} \mathrm{SO}_{4}$ ratio used, which was more than at $600^{\circ} \mathrm{C}$. 

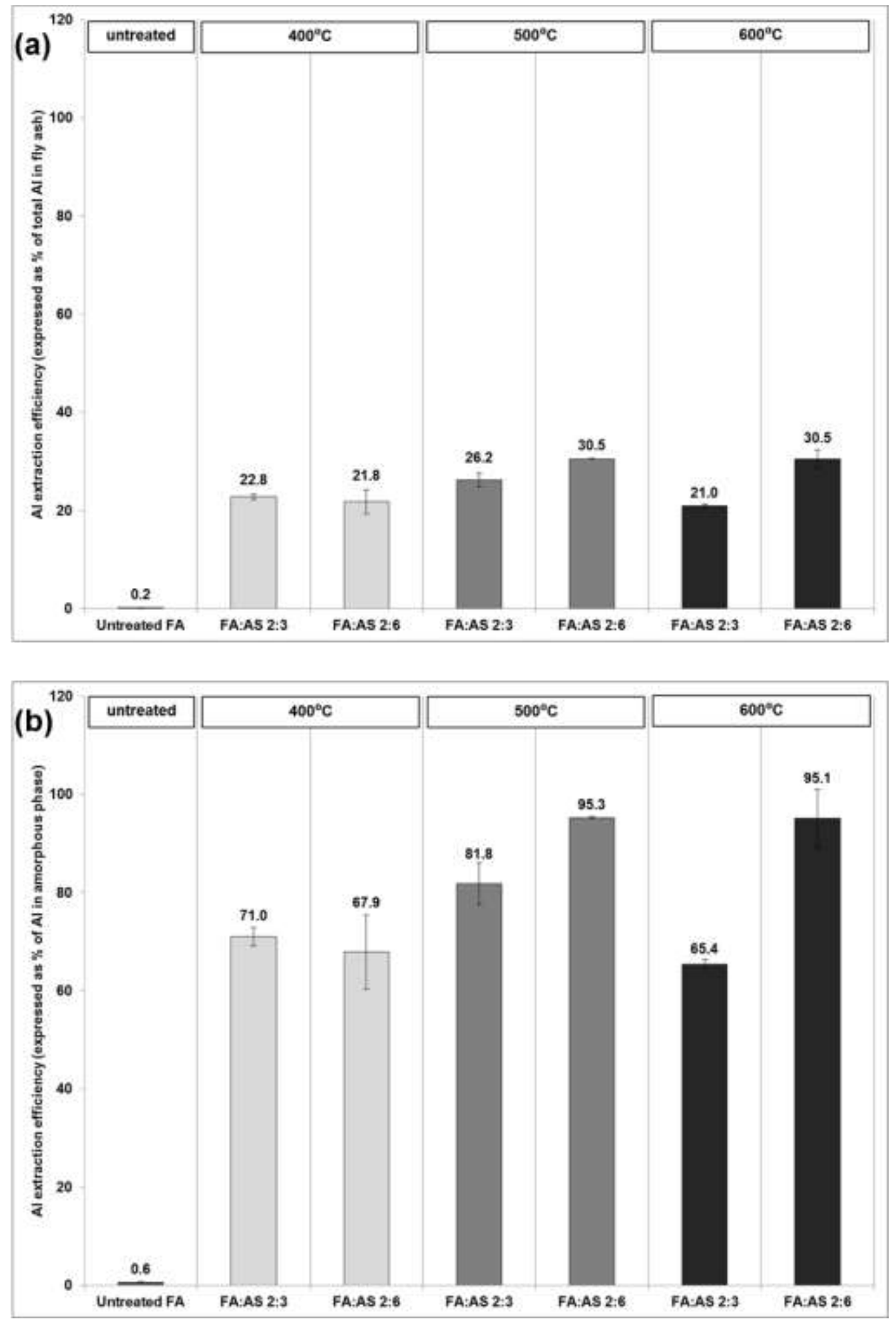

Figure 3 Aluminium extraction efficiency (A. expressed as \% of total aluminium in CFA; B. expressed as \% of Al in amorphous phase) at two different CFA: $\left(\mathrm{NH}_{4}\right)_{2} \mathrm{SO}_{4}$ ratios (FA:AS of $2: 3$ and $\left.2: 6\right)$ and three activation temperatures $\left(400^{\circ} \mathrm{C}, 500^{\circ} \mathrm{C}, 600^{\circ} \mathrm{C}\right)(n$ $=2$ ). 
Table 2 Semi-quantitative mineralogical analysis of fly ash thermochemically-treated at CFA: $\left(\mathrm{NH}_{4}\right)_{2} \mathrm{SO}_{4}$ ratios of 2:3 and 2:6 and at a temperature of $500^{\circ} \mathrm{C}$ (Reaction time: $1 \mathrm{~h}$; Chemical agent used: $\left(\mathrm{NH}_{4}\right)_{2} \mathrm{SO}_{4}$; only the crystalline phases are reported and were normalized to $100 \%)$.

\begin{tabular}{|c|c|c|c|c|}
\hline Minerals & Chemical formula & $\begin{array}{l}\text { Untreated } \\
\text { fly ash }\end{array}$ & $\begin{array}{c}\text { CFA: }\left(\mathrm{NH}_{4}\right)_{2} \mathrm{SO}_{4} \text { ratio } \\
2: 3\end{array}$ & CFA: $\left(\mathrm{NH}_{4}\right)_{2} \mathrm{SO}_{4}$ ratio $2: 6$ \\
\hline Mullite & $\mathrm{Al}_{6} \mathrm{Si}_{2} \mathrm{O}_{13}$ & 84.3 & 17 & 9 \\
\hline Quartz & $\mathrm{SiO}_{2}$ & 15.5 & 9 & 6 \\
\hline Lime & $\mathrm{CaO}$ & 0.2 & n.d. & n.d. \\
\hline Anhydrite & $\mathrm{CaSO}_{4}$ & n.d. & 27 & 19 \\
\hline Millosevichite & $\mathrm{Al}_{2}\left(\mathrm{SO}_{4}\right)_{3}$ & n.d. & 26 & 20 \\
\hline Godovikovite & $\mathrm{NH}_{4} \mathrm{Al}\left(\mathrm{SO}_{4}\right)_{2}$ & n.d. & 21 & 46 \\
\hline
\end{tabular}

n.d.: not detected

CFA processed at $400^{\circ} \mathrm{C}$ exhibited a much more complex mineralogical composition containing a mixture of unreacted parent silicate minerals $\left(\mathrm{Al}_{6} \mathrm{Si}_{2} \mathrm{O}_{13}+\mathrm{SiO}_{2}\right)$, and new crystalline $\mathrm{Al}-\left(\mathrm{Al}_{2}\left(\mathrm{SO}_{4}\right)_{3}+\mathrm{NH}_{4} \mathrm{Al}\left(\mathrm{SO}_{4}\right)_{2}\right)$ and $\mathrm{Ca}$ - $\left(\mathrm{CaSO}_{4}\right)$ containing phases. These minerals were embedded in a matrix composed of two products of thermal decomposition of $\left(\mathrm{NH}_{4}\right)_{2} \mathrm{SO}_{4}$ (i.e. $\left.\mathrm{NH}_{4} \mathrm{HSO}_{4}+\left(\mathrm{NH}_{4}\right)_{3} \mathrm{H}\left(\mathrm{SO}_{4}\right)_{2}\right)$ that had yet to react with CFA (Table 3). Since these unreacted ammonium-based sulphate compounds are water-soluble, they most certainly contributed to the high electrical conductivity values measured in their corresponding leachates (Figure 2B). Anhydrite represented no more than $6 \%$ of the crystalline structure. 
Table 3 Semi-quantitative mineralogical analysis of fly ash thermochemically-treated at CFA: $\left(\mathrm{NH}_{4}\right)_{2} \mathrm{SO}_{4}$ ratios of 2:3 and 2:6 and at a temperature of $400^{\circ} \mathrm{C}$ (Reaction time: $1 \mathrm{~h}$; Chemical agent used: $\left(\mathrm{NH}_{4}\right)_{2} \mathrm{SO}_{4}$; only the crystalline phases are reported and were normalized to $100 \%)$.

\begin{tabular}{|c|c|c|c|c|}
\hline Minerals & Chemical formula & $\begin{array}{l}\text { Untreated } \\
\text { fly ash }\end{array}$ & $\begin{array}{c}\text { CFA: }\left(\mathrm{NH}_{4}\right)_{2} \mathrm{SO}_{4} \text { ratio } \\
2: 3\end{array}$ & CFA: $\left(\mathrm{NH}_{4}\right)_{2} \mathrm{SO}_{4}$ ratio $2: 6$ \\
\hline Mullite & $\mathrm{Al}_{6} \mathrm{Si}_{2} \mathrm{O}_{13}$ & 84.3 & 6 & 4 \\
\hline Quartz & $\mathrm{SiO}_{2}$ & 15.5 & 3 & 3 \\
\hline Lime & $\mathrm{CaO}$ & 0.2 & n.d. & n.d. \\
\hline Anhydrite & $\mathrm{CaSO}_{4}$ & n.d. & 6 & 3 \\
\hline Millosevichite & $\mathrm{Al}_{2}\left(\mathrm{SO}_{4}\right)_{3}$ & n.d. & 5 & 2 \\
\hline Godovikovite & $\mathrm{NH}_{4} \mathrm{Al}\left(\mathrm{SO}_{4}\right)_{2}$ & n.d. & 24 & 16 \\
\hline Letovicite & $\left(\mathrm{NH}_{4}\right)_{3} \mathrm{H}\left(\mathrm{SO}_{4}\right)_{2}$ & n.d. & 14 & 20 \\
\hline $\begin{array}{l}\text { Ammonium } \\
\text { hydrogen } \\
\text { sulphate }\end{array}$ & $\mathrm{NH}_{4} \mathrm{HSO}_{4}$ & n.d. & 42 & 52 \\
\hline
\end{tabular}

n.d.: not detected

\subsubsection{Morphological characterisation}

The morphology of thermochemically-treated CFA was observed by FE-SEM. For comparison, untreated CFA particles were also examined (Figure 4a). The latter was composed of individual spherical or "ballbearing" particles of varying sizes, as well as clusters of particles. The surface topography of CFA spheres was relatively smooth at the scale of observation allowed by the FE-SEM, regardless of the particle size. On the other hand, thermochemically-treated CFA consisted of spherical CFA particles surrounded by numerous newly-formed hexagonal structures that were mostly interlocked to form clusters of varying sizes (Figure 4b). Depending on the treatment temperature, these hexagonal structures may have been millosevichite $\left(\mathrm{Al}_{2}\left(\mathrm{SO}_{4}\right)_{3}\right)$ and/or godovikovite $\left(\mathrm{NH}_{4} \mathrm{Al}\left(\mathrm{SO}_{4}\right)_{2}\right)$ as identified by $\mathrm{XRD}$, since these minerals are crystals of hexagonal configuration (millosevichite [31]; godovikovite [32]). At high magnification, the hexagons exhibited cracked surfaces (Figure 5a) with plate-like shapes (Figure 5b). Other highmagnification micrographs (Figures $5 c-d$ ) also showed the occurrence of orthorhombic or cubic lattices 

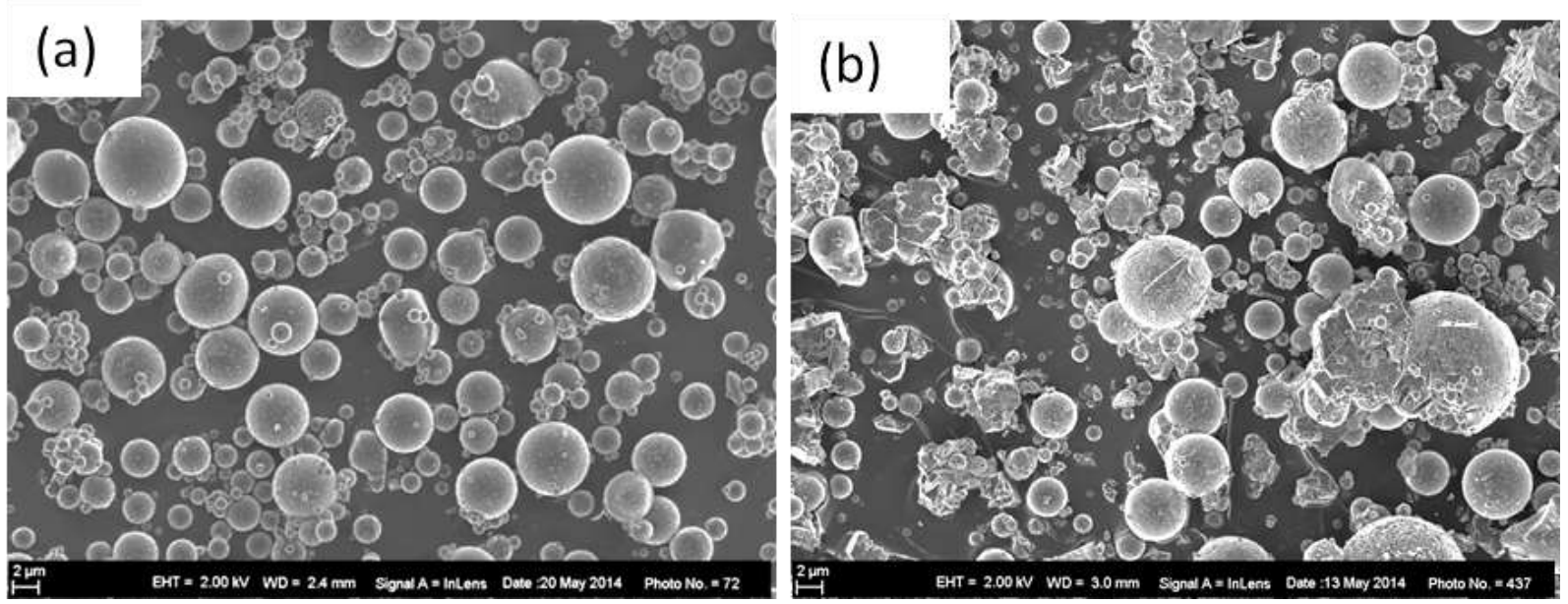

Figure 4 FE-SEM micrographs of (a) untreated fly ash, and (b) fly ash thermochemically-treated at $600^{\circ} \mathrm{C}$ using $\mathrm{CFA}^{\circ}\left(\mathrm{NH}_{4}\right)_{2} \mathrm{SO}_{4}$ ratio of 2:6. Acceleration voltage: $2 \mathrm{kV}$; Magnification: 5000x.
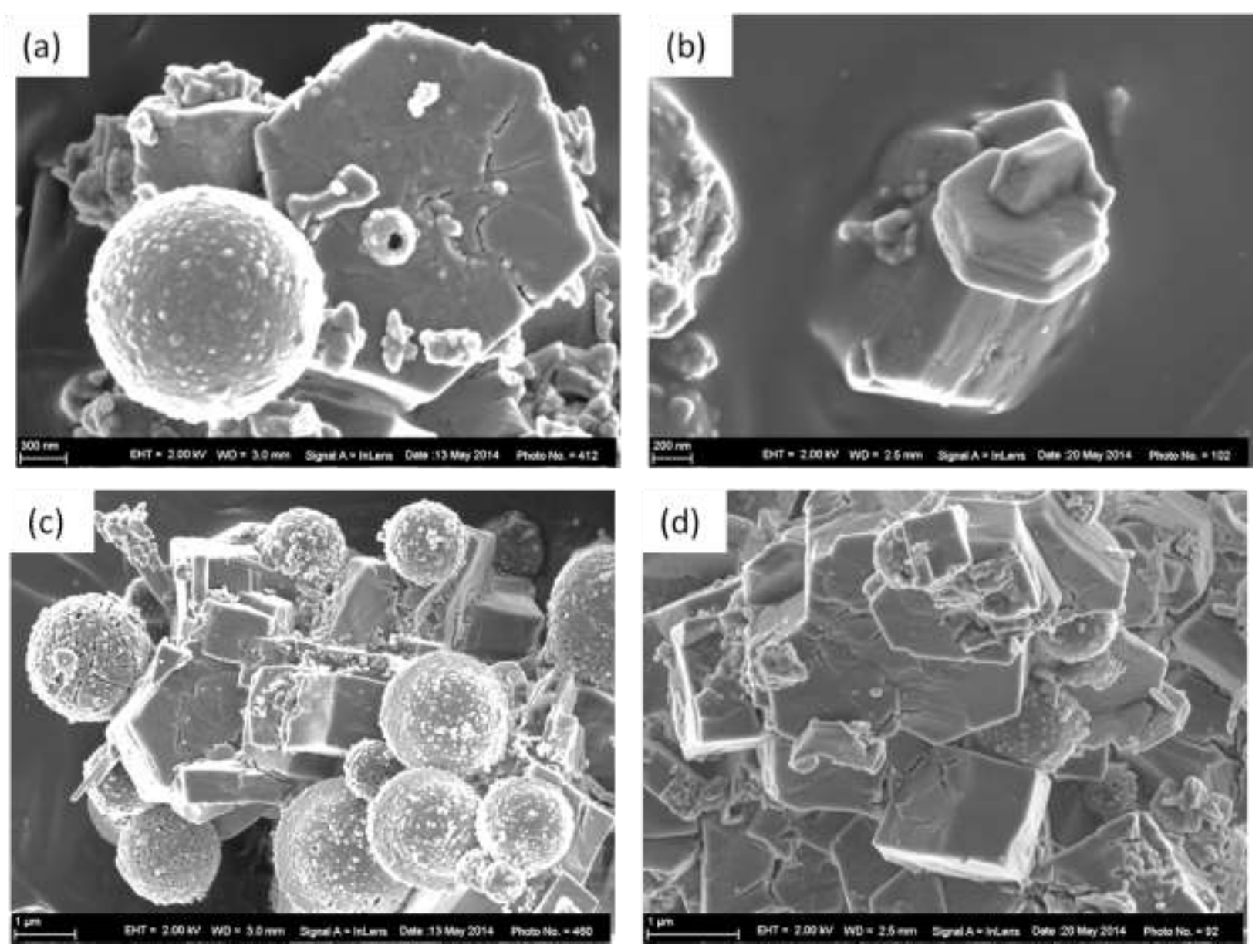

Figure 5 High-magnification FE-SEM micrographs of hexagonal (75000x (a), 95000x (b)) and orthorhombic/cubic (30000x (c), $45000 x(d))$ structures present in fly ash sample thermochemically-treated at $600^{\circ} \mathrm{C}$ (acceleration voltage: $2 \mathrm{kV}$ ). 
in the clusters made up of hexagonal structures and CFA particles, with sides of about $1 \mu \mathrm{m}$. These lattices corresponded most probably to the anhydrite mineral $\left(\mathrm{CaSO}_{4}\right)$ identified by XRD (Tables 1-3), since the crystal structure system of anhydrite is orthorhombic, which can also result in cleavage in smaller cubes [33].

\subsection{Effect of thermochemical processing of coal fly ash on aluminium extraction}

The chemical extraction of Al from untreated and thermochemically-treated CFA dispersed in ultra-pure water (i.e. under uncontrolled $\mathrm{pH}$ conditions) was investigated by initially monitoring the profile of two solution parameters over time: $\mathrm{pH}$ and conductivity (Figure 2). For untreated CFA, solution $\mathrm{pH}$ increased rapidly before progressively plateauing and stabilizing at 9.61 . This was accompanied by a slight increase in solution conductivity ( $c a .290 \mu \mathrm{S} / \mathrm{cm}$ ). These observations could be ascribed to some leaching of alkalis and alkaline earths and other metal ions from the glass phase [34]. For instance, the content of calcium ( $\mathrm{Ca}$ ) in CFA exerts a strong influence on the $\mathrm{pH}$ of the ash-water system.

Dispersing thermochemically-treated CFA in ultra-pure water introduced very distinct temporal changes to the $\mathrm{pH}$ and conductivity of the solution when compared to those observed with untreated CFA. For instance, the rapid decrease of the solution $\mathrm{pH}$ below 4 immediately upon addition of all treated CFA was the first indication that CFA had undergone significant structural changes. This low $\mathrm{pH}$ could not be solely explained by the presence of excess $\left(\mathrm{NH}_{4}\right)_{2} \mathrm{SO}_{4}$ remaining in activated CFA since $\left(\mathrm{NH}_{4}\right)_{2} \mathrm{SO}_{4}$ solutions typically have a $\mathrm{pH}$ in the range of 5 to 6 , and most of the salt is expected to be decomposed at temperatures $\geq 500^{\circ} \mathrm{C}$. However, it represented the first indirect evidence that water-soluble metal

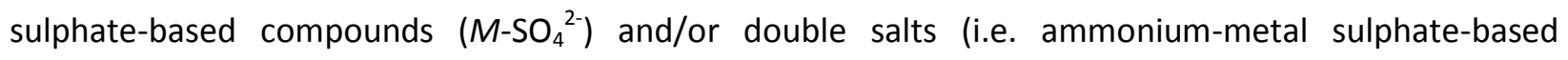
compounds; $\mathrm{NH}_{4}{ }^{+}-\mathrm{M}_{-} \mathrm{SO}_{4}{ }^{2-}$ ) may have formed during the thermochemical process since chemical species such as $\mathrm{Al}_{2}\left(\mathrm{SO}_{4}\right)_{3}$ are very acidic. The CFA: $\left(\mathrm{NH}_{4}\right)_{2} \mathrm{SO}_{4}$ ratio had little effect on solution $\mathrm{pH}$ under the experimental conditions tested (Figure 2A). In contrast, the temperature used during thermochemical processing played a significant role (Figure $2 \mathrm{~A}$ ), with a temperature of $400^{\circ} \mathrm{C}$ promoting a lower $\mathrm{pH}$ (1.61-1.74) than elevated temperatures $\left(2.91-2.95\right.$ at $500^{\circ} \mathrm{C} ; 3.31-3.49$ at $\left.600^{\circ} \mathrm{C}\right)$. In a similar manner, leaching of CFA thermochemically-treated at $400^{\circ} \mathrm{C}$ resulted in higher solution conductivity (> 8000 $\mu \mathrm{S} / \mathrm{cm})$ than for CFA treated at higher temperatures $\left(3157-3430 \mu \mathrm{S} / \mathrm{cm}\right.$ at $500^{\circ} \mathrm{C} ; 1822-2470 \mu \mathrm{S} / \mathrm{cm}$ at $\left.600^{\circ} \mathrm{C}\right)$. In addition, greater $\mathrm{CFA}:\left(\mathrm{NH}_{4}\right)_{2} \mathrm{SO}_{4}$ ratios led to higher conductivity values (Figure $2 \mathrm{~B}$ ). This observation was particularly dominant at $400^{\circ} \mathrm{C}$, which suggested that an excess of $\left(\mathrm{NH}_{4}\right)_{2} \mathrm{SO}_{4}$ had been 
used at this temperature and was still present in the reaction product because it had most probably not fully reacted with CFA and it had not fully decomposed into volatile gases. It is therefore conceivable that increasing the duration of the thermochemical processing step at this temperature may have a positive effect on the extent of $\mathrm{Al}$ extraction. No $\left(\mathrm{NH}_{4}\right)_{2} \mathrm{SO}_{4}$ or associated decomposition species (e.g. $\mathrm{NH}_{4} \mathrm{HSO}_{4}$ ) were expected to be present in the solids generated at higher temperatures. As a result, the difference in solution conductivity observed for the two CFA: $\left(\mathrm{NH}_{4}\right)_{2} \mathrm{SO}_{4}$ ratios at higher temperatures can most likely be explained in terms of differences in dissolved Al and other metals. In particular, the positive effect of increased CFA: $\left(\mathrm{NH}_{4}\right)_{2} \mathrm{SO}_{4}$ ratio on the extent of Al extraction appeared to be greater at $600^{\circ} \mathrm{C}$ than at $500^{\circ} \mathrm{C}$.

Extraction of Al from untreated and thermochemically-treated CFA was also evaluated. The total content of $\mathrm{Al}$ in as-received, untreated CFA was 34.0\% (expressed as $\mathrm{Al}_{2} \mathrm{O}_{3}$ ), which corresponds to 17.99g Al/100g CFA. The speciation of Al in CFA was two-fold. CFA contained a crystalline mullite phase $\left(\mathrm{Al}_{6} \mathrm{Si}_{2} \mathrm{O}_{13} ; 31.8 \%\right)$, which is theoretically composed of $38 \%$ of $\mathrm{Al}$, and a glass phase which comprised the remaining Al. This implied that $11.47 \mathrm{~g}$ of $\mathrm{Al}$ was trapped in the potentially unreactive mullite fraction and $6.52 \mathrm{~g}$ of $\mathrm{Al}$ was distributed in the structure of the presumably more reactive glass phase. It was anticipated that $\mathrm{Al}$ present in the glass phase would react more extensively with $\left(\mathrm{NH}_{4}\right)_{2} \mathrm{SO}_{4}$ and/or its derived species generated during its thermal decomposition (e.g. $\mathrm{NH}_{4} \mathrm{HSO}_{4},\left(\mathrm{NH}_{4}\right)_{3} \mathrm{H}\left(\mathrm{SO}_{4}\right)_{2},\left(\mathrm{NH}_{4}\right)_{2} \mathrm{~S}_{2} \mathrm{O}_{7}$; [26]) than the Al confined in the mullite component. For this reason, Al extraction efficiency was calculated both as a percentage of total $\mathrm{Al}\left(\mathrm{Al}_{\text {tot }}\right)$ present in CFA (Figure $3 \mathrm{~A}$ ) and as a percentage of $\mathrm{Al}$ present in the amorphous phase ( $\mathrm{Al}_{\text {glass; }}$ Figure $\left.3 \mathrm{~B}\right)$.

(a) Untreated CFA - Dissolution of untreated CFA in ultra-pure water was minimal. In particular, little Al $\left(0.2 \%\right.$ of $\mathrm{Al}_{\text {tot }} ; 0.6 \%$ of $\left.\mathrm{Al}_{\text {glass }}\right)$ had been released to solution; this was in agreement with the low electrical conductivity value measured (ca. $290 \mu \mathrm{S} / \mathrm{cm}$ ).

(b) Thermochemically-treated CFA - The extent of aqueous Al extraction from CFA improved substantially following its thermochemical processing using $\left(\mathrm{NH}_{4}\right)_{2} \mathrm{SO}_{4}$ and was greater than $21.0 \%$ of $\mathrm{Al}_{\text {tot }}$ or $65.4 \%$ of $\mathrm{Al}_{\text {glass }}$ for all experimental conditions studied (Figure 3). Different combinations of processing temperature and CFA: $\left(\mathrm{NH}_{4}\right)_{2} \mathrm{SO}_{4}$ ratio resulted in varying concentrations of $\mathrm{Al}$ in the filtrates. For the duration of the thermochemical processing step used in this study (i.e. $1 \mathrm{~h}$ ) and at a CFA: $\left(\mathrm{NH}_{4}\right)_{2} \mathrm{SO}_{4}$ ratio of 2:6, an improvement in Al extraction efficiency was observed when the temperature had been increased from $400^{\circ} \mathrm{C}\left(21.8 \%\right.$ of $\mathrm{Al}_{\text {tot }} ; 67.9 \%$ of $\left.\mathrm{Al}_{\text {glass }}\right)$ to $500^{\circ} \mathrm{C}\left(30.5 \%\right.$ of $\mathrm{Al}_{\text {tot }}$; 
95.3\% of $A l_{\text {glass }}$ ). A further increase to $600^{\circ} \mathrm{C}$ did not increase the extent of $\mathrm{Al}$ extraction $(30.5 \%$ of $\mathrm{Al}_{\text {tot }} ; 95.1 \%$ of $\left.\mathrm{Al}_{\text {glass }}\right)$. Reducing the CFA: $\left(\mathrm{NH}_{4}\right)_{2} \mathrm{SO}_{4}$ ratio from 2:6 to 2:3 had no effect on the concentration of dissolved Al for CFA activated at $400^{\circ} \mathrm{C}$. This was a strong indication that the chemical additive was present in excess for the two investigated conditions. Since less Al was extracted at this temperature than at $500 / 600^{\circ} \mathrm{C}$ and no other easily leachable elements were present in sufficiently large quantity in CFA, the higher solution conductivity measured for the $400^{\circ} \mathrm{C}$ treatment was most probably generated by the release of $\mathrm{NH}_{4}{ }^{+}$and $\mathrm{SO}_{4}{ }^{2-}$ ions from unreacted water-soluble $\left(\mathrm{NH}_{4}\right)_{2} \mathrm{SO}_{4}$ and/or its derived species generated during its thermal decomposition after the $1 \mathrm{~h}$ activation step. Reducing the CFA: $\left(\mathrm{NH}_{4}\right)_{2} \mathrm{SO}_{4}$ ratio from 2:6 to 2:3 had a measurable negative effect on the concentration of dissolved Al for CFA thermochemically-treated at elevated temperatures $\left(500^{\circ} \mathrm{C}\right.$ and $\left.600^{\circ} \mathrm{C}\right)$. The lower extraction of $\mathrm{Al}$ for CFA treated at $600^{\circ} \mathrm{C}$ compared to that treated at $500^{\circ} \mathrm{C}$ suggested that at a CFA: $\left(\mathrm{NH}_{4}\right)_{2} \mathrm{SO}_{4}$ of 2:3 the kinetics of thermal decomposition and volatilisation of $\left(\mathrm{NH}_{4}\right)_{2} \mathrm{SO}_{4}$ at $600^{\circ} \mathrm{C}$ had been more rapid than the rate of reaction between the extracting agent and CFA.

A CFA: $\left(\mathrm{NH}_{4}\right)_{2} \mathrm{SO}_{4}$ of $2: 6$ at $500^{\circ} \mathrm{C}$ was the optimal condition for the selective extraction of $\mathrm{Al}$ from the amorphous phase of CFA when a 1h-long thermochemical treatment was used. Significant extraction of Al from the mullite component appeared unlikely under the experimental conditions tested since FE-SEM observations of treated CFA did not provide any evidence of mullite crystals having been exposed to the extracting agent, although it could not be unambiguously demonstrated at this stage. This is currently being investigated in greater details in our laboratories.

\subsection{Simultaneous extraction of other elements}

Under all experimental conditions tested, the process permitted to selectively extract $\mathrm{Al}$ over $\mathrm{Si}$, with less than $0.6 \%$ Si having been released from quartz, mullite and the amorphous glass phase to solution. This was not specific to the mineralogy of CFA, and a similar observation was also made for other aluminosilicate materials (e.g. 0.8\% from Portuguese serpentinite [35]). However, tailings associated with the mining of Platinum Group Metals (PGM) have been shown to release significant amounts of Si to solution (18\%; Mohamed et al., 2016) following similar thermochemical processing with $\left(\mathrm{NH}_{4}\right)_{2} \mathrm{SO}_{4}$. The minimal extraction of Si from CFA was an important finding, since some applications require Al sources which are Si-depleted. 

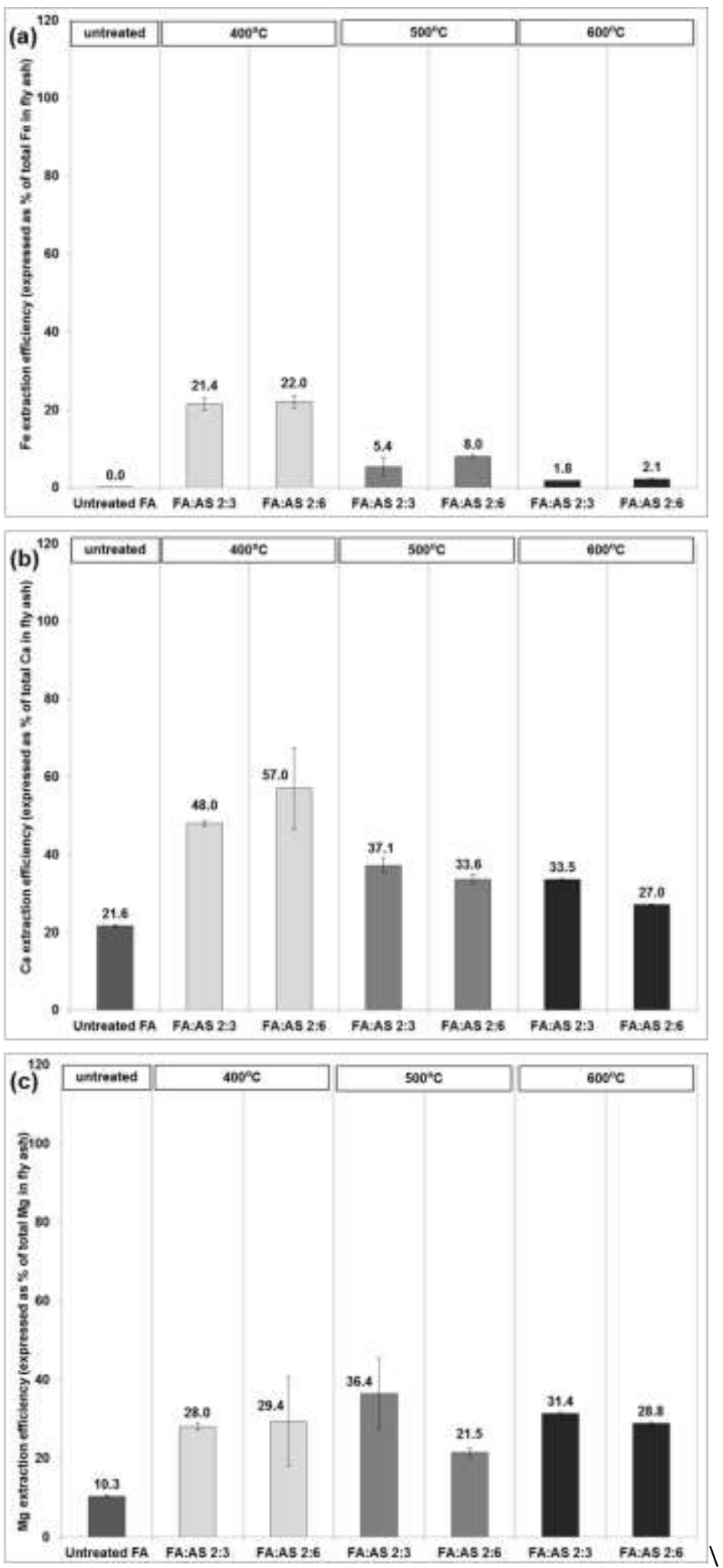

Figure 6 Iron (A.), calcium (B.), magnesium (C.) and titanium (D.) extraction efficiency (expressed as \% of total element in CFA) at two different CFA: $\left(\mathrm{NH}_{4}\right)_{2} \mathrm{SO}_{4}$ ratios (FA:AS of $2: 3$ and $\left.2: 6\right)$ and three activation temperatures $\left(400^{\circ} \mathrm{C}, 500^{\circ} \mathrm{C}, 600^{\circ} \mathrm{C}\right)(n=2)$. 
However, apart from $\mathrm{Si}$, the process was not element-specific, and the chemical affinity between $\left(\mathrm{NH}_{4}\right)_{2} \mathrm{SO}_{4}$ and other major elements under thermal conditions led to the co-extraction of calcium, magnesium, iron and titanium (Figure 6). Similar observation of combined metal extraction was previously made for a range of thermochemically-treated silicate and oxide minerals [26,35-36]. In the present study, the extraction of $\mathrm{Ca}, \mathrm{Ti}$ and Fe was found to decrease with increasing temperature, which represented an opposite trend to that of Al. Although optimal Al extraction was obtained when using a CFA: $\left(\mathrm{NH}_{4}\right)_{2} \mathrm{SO}_{4}$ of $2: 6$ at $500^{\circ} \mathrm{C}$, ca. $8 \% \mathrm{Fe}$ was co-extracted. Increasing the treatment temperature to $600^{\circ} \mathrm{C}$ reduced Fe extraction down to ca. $2 \%$, presumably due to varying thermodynamic control of occurring reactions at various temperatures, with no negative effect on Al extraction. This information may be significant for applications where the presence or contamination by Fe may be problematic. However, elevated temperatures during thermochemical treatment lead to $\left(\mathrm{NH}_{4}\right)_{2} \mathrm{SO}_{4}$ reagent losses due to its excessive decomposition (i.e. loss as $\mathrm{SO}_{\mathrm{x}}$ ), which must be minimized to ensure a closed loop process with recoverable reagent [37]. Changes to key process variables for thermochemical treatment below $500^{\circ} \mathrm{C}$ are currently being investigated, with the aim of minimizing reagent loss with minimal negative impact on Al extraction, although higher $\mathrm{Ca}$ and Ti extraction efficiencies are anticipated under these temperature conditions.

\subsection{Characterisation of non-dissolved residues $\left(C F A_{\text {res }}\right)$}

XRD revealed the presence of mullite and quartz, the two primary crystalline phases present in

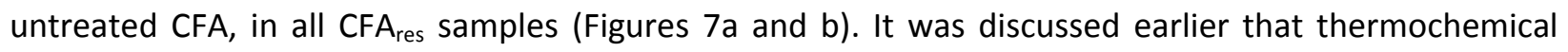
treatment of CFA had induced the formation of several mineralogical phases (Figure 1), which included anhydrite $\mathrm{CaSO}_{4}$ and millosevichite $\mathrm{Al}_{2}\left(\mathrm{SO}_{4}\right)_{3}$ (Tables 1 to 3), godovikovite $\mathrm{NH}_{4} \mathrm{Al}\left(\mathrm{SO}_{4}\right)_{2}$ (Tables 2 and 3), and letovicite $\left(\mathrm{NH}_{4}\right)_{3} \mathrm{H}\left(\mathrm{SO}_{4}\right)_{2}$ and ammonium hydrogen sulphate $\mathrm{NH}_{4} \mathrm{HSO}_{4}$ (Table 3). Four of the newlyformed species (anhydrite, millosevichite, letovicite and ammonium hydrogen sulphate) were absent

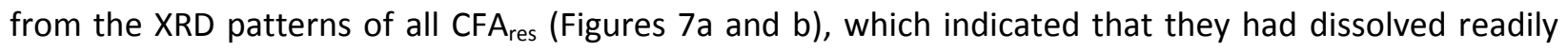
during the timeframe of the experiments. In contrast, godovikovite was identified in all CFA $\mathrm{res}_{\text {res }}$ originating from $\mathrm{MT}_{\text {tct }}$ that had contained the mineral (Figures $7 \mathrm{a}$ and $\mathrm{b}$ ). This indicated that godovikovite had not, or only partially, dissolved during leaching. This phase may also have transformed, in part, to the intermediate species tschermigite $\left(\mathrm{NH}_{4} \mathrm{Al}\left(\mathrm{SO}_{4}\right)_{2} \cdot 12 \mathrm{H}_{2} \mathrm{O}\right.$, which was identified in the XRD patterns of CFA ${ }_{\text {res }}$ for experiments where the thermochemical step made use of a CFA: $\left(\mathrm{NH}_{4}\right)_{2} \mathrm{SO}_{4}$ ratio of 2:6 (Figure 

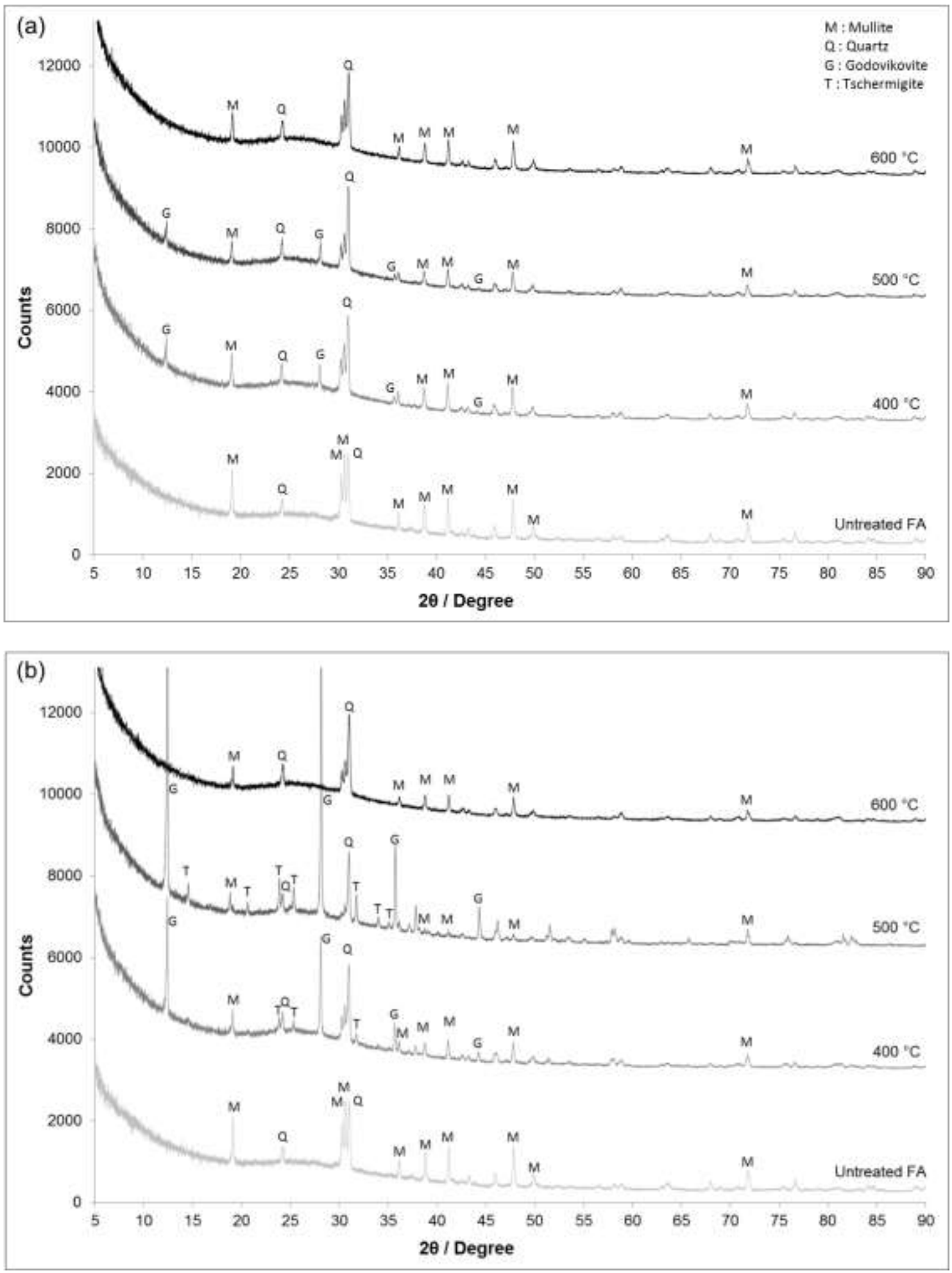

Figure 7 XRD analysis of untreated fly ash and non-dissolved residues generated following aqueous leaching of fly ash thermochemically-treated at three temperatures $\left(400,500\right.$ and $\left.600^{\circ} \mathrm{C}\right)$ at the two CFA: $\left(\mathrm{NH}_{4}\right)_{2} \mathrm{SO}_{4}$ ratios of (a) 2:3 and (b) 2:6. 
7b). It is therefore recommended to select thermochemical conditions that favour the formation of millosevichite over that of godovikovite.

$\mathrm{CFA}_{\text {res }}$ contained less $\mathrm{Al}, \mathrm{Ca}$ and Fe, but more Si, than untreated CFA (Table 4). This observation was in agreement with the trends observed in elemental extraction efficiencies discussed in Sections 3.3 and 3.4. The content of $\mathrm{SO}_{3}$ was low in $\mathrm{CFA}_{\text {res }}$ originating from thermochemical treatment at $600^{\circ} \mathrm{C}$ followed by dissolution ( $\leq 0.80 \%)$. In contrast, it amounted to $1.40-1.43 \%$ when a CFA: $\left(\mathrm{NH}_{4}\right)_{2} \mathrm{SO}_{4}$ ratio of 2:3 had been used, whereas the values were much greater (3.99-6.95\%) when a larger excess of $\left(\mathrm{NH}_{4}\right)_{2} \mathrm{SO}_{4}$ had been utilised at $400^{\circ} \mathrm{C}$ and $500^{\circ} \mathrm{C}$ (Table 4). The observation of elevated amounts of $\mathrm{SO}_{3}$ appeared to relate positively with the presence of godovikovite and tschermigite in the XRD patterns of CFA $A_{\text {res }}$. The

Table 4 Chemical compositions of untreated fly ash and non-dissolved residues generated following aqueous leaching of fly ash thermochemically-treated at three temperatures $\left(400,500\right.$ and $\left.600^{\circ} \mathrm{C}\right)$ and at the two CFA: $\left(\mathrm{NH}_{4}\right)_{2} \mathrm{SO}_{4}$ ratios of 2:3 and 2:6, as determined by XRF. Only major elements are reported.

\begin{tabular}{|c|c|c|c|c|c|c|c|}
\hline & \multirow{2}{*}{$\begin{array}{l}\text { Untreated } \\
\text { fly ash }\end{array}$} & \multicolumn{3}{|c|}{ CFA: $\left(\mathrm{NH}_{4}\right)_{2} \mathrm{SO}_{4}$} & \multicolumn{3}{|c|}{$\begin{array}{c}\text { CFA: }\left(\mathrm{NH}_{4}\right)_{2} \mathrm{SO}_{4} \\
\text { ratio 2:6 }\end{array}$} \\
\hline & & $400^{\circ} \mathrm{C}$ & $500^{\circ} \mathrm{C}$ & $600^{\circ} \mathrm{C}$ & $400^{\circ} \mathrm{C}$ & $500^{\circ} \mathrm{C}$ & $600^{\circ} \mathrm{C}$ \\
\hline $\mathrm{SiO}_{2}$ & 49.30 & 59.80 & 58.80 & 58.50 & 57.90 & 55.50 & 60.70 \\
\hline $\mathrm{Al}_{2} \mathrm{O}_{3}$ & 34.00 & 28.10 & 27.10 & 29.20 & 26.80 & 23.80 & 26.10 \\
\hline $\mathrm{Fe}_{2} \mathrm{O}_{3}$ & 5.78 & 2.75 & 3.46 & 3.56 & 2.85 & 3.42 & 3.64 \\
\hline $\mathrm{CaO}$ & 5.06 & 2.68 & 3.52 & 3.40 & 3.07 & 3.25 & 3.50 \\
\hline $\mathrm{TiO}_{2}$ & 2.01 & 1.86 & 2.14 & 2.07 & 1.71 & 1.96 & 2.14 \\
\hline $\mathrm{MgO}$ & 0.99 & 0.82 & 0.96 & 0.78 & 0.86 & 0.88 & 0.90 \\
\hline $\mathrm{K}_{2} \mathrm{O}$ & 0.87 & 0.87 & 0.70 & 0.66 & 0.76 & 0.55 & 0.73 \\
\hline $\mathrm{P}_{2} \mathrm{O}_{5}$ & 0.59 & 0.58 & 0.66 & 0.70 & 0.25 & 0.44 & 0.65 \\
\hline $\mathrm{SO}_{3}$ & 0.24 & 1.40 & 1.43 & 0.37 & 3.99 & 6.95 & 0.80 \\
\hline LOI & 0.52 & 0.65 & 0.52 & 0.28 & 1.23 & 2.60 & 0.40 \\
\hline Total & 99.36 & 99.51 & 99.29 & 99.52 & 99.42 & 99.35 & 99.55 \\
\hline
\end{tabular}


LOI values were fairly similar to that for untreated CFA, except for the samples where a greater $\mathrm{SO}_{3}$ had been found, which were characterised by a LOI varying between 1.23 and 2.60 (Table 4). Higher LOI values were most probably the result of the dehydration of tschermigite, which contains 12 molecules of water.

\section{Conclusions}

The potential for selectively extracting Al from the amorphous glass phase of an ultrafine coal fly ash was demonstrated in this study, with extraction efficiencies of up to $95.0 \%$ achieved. Since Al was most probably not extracted from the mullite component of CFA, different coal ashes could be ranked on the basis of their mullite and amorphous contents. The process involved thermochemical treatment using $\left(\mathrm{NH}_{4}\right)_{2} \mathrm{SO}_{4}$, a widely available, low-cost, recyclable extracting agent, followed by aqueous dissolution at ambient temperature. The process was not element-selective, and the chemical affinity between $\left(\mathrm{NH}_{4}\right)_{2} \mathrm{SO}_{4}$ and a number of elements (e.g. calcium, magnesium, titanium) under thermal conditions led to the formation of several water-soluble sulphate-metal species. However, thermochemical treatment at $600^{\circ} \mathrm{C}$ permitted the selective extraction of aluminium (ca. 95\%) over iron (ca. $2 \%$ ) and silicon ( $<$ $0.6 \%)$, which may be important for some applications. This extraction process offers the significant advantage of recovering aluminium from CFA in a readily-available soluble form, which could be subsequently converted to value-added products. The latter could enable the economical usage and therefore viability of ash management via valorisation. The process yields a silicon-rich residue, which could be used as a secondary source of e.g. nano-silica. The envisaged modes of use of ash could substantially reduce the volumes of ash dams, and could contribute to the sustainability of the South African aluminium sector and to reduction of penalties imposed on power generators for ash accumulation.

\section{Acknowledgement}

The project was financially supported by the Council for Geoscience, the University of Pretoria and the National Research Foundation of South Africa (NRF; Grant No.93641). The authors thank Ms Marolien Kleynhans for technical assistance. Dr Richard Kruger is acknowledged for his valuable intellectual contribution, Ms Wiebke Grote for XRD, Ms Jeanette Dykstra for XRF, the University of Pretoria Laboratory for Microscopy and Microanalysis for assistance with FE-SEM, and Ash Resources (Pty) Ltd 
for providing the fly ash sample. Any opinion, finding and conclusion or recommendation expressed in this material is that of the authors and the NRF does not accept any liability in this regard.

\section{References}

[1] Eskom (2011) Partnering for a sustainable future. Integrated report (obtained from: www.eskom.co.za, on $23^{\text {rd }}$ August 2012).

[2] Mahlaba, J.S., Kearsley, E.P., Kruger, R.A. (2011) Physical, chemical and mineralogical characterisation of hydraulically disposed fine coal ash from SASOL Synfuels. Fuel 90, 2491-2500.

[3] Guo, Y., Li, Y., Cheng, F., Wang, M., Wang, X. (2013) Role of additives in improved thermal activation of coal fly ash for alumina extraction. Fuel Processing Technology 110, 114-121.

[4] Li, H., Hui, J., Wang, C., Bao, W., Sun, Z. (2014) Extraction of alumina from coal fly ash by mixedalkaline hydrothermal method. Hydrometallurgy 147-148, 183-187.

[5] Shemi, A., Ndlovu, S., Sibanda, V., van Dyk, L.D. (2014) Extraction of aluminium from coal fly ash: Identification and optimization of influential factors using statistical design of experiments. International Journal of Mineral Processing 127, 10-15.

[6] Yao, Z.T., Xia, M.S., Sarker, P.K., Chen, T. (2014) A review of the alumina recovery from coal fly ash, with a focus in China. Fuel 120, 74-85.

[7] Zhu, P.W., Dai, H., Han, L., Xu, X.L., Cheng, L.M., Wang, Q.H., Shi, Z.L. (2015) Aluminum extraction from coal ash by a 2-step acid leaching method. Journal of Zhejiang University-SCIENCE A (Applied Physics \& Engineering) 16, 161-169.

[8] Yao, Z.T., Ji, X.S., Sarker, P.K., Tank, J.H., Ge, L.K., Xia, M.S., Xi, Y.Q. (2015) A comprehensive review on the applications of coal fly ash. Earth-Science Reviews 141, 105-121.

[9] Tolhurst, L. (2015) Commercial recovery of metals from coal ash. 2015 Proceedings of the World of Coal Ash (WOCA) Conference, Nashville, USA, May 2-7, http://www.flyash.info/2015/185-tolhurst2015.pdf 
[10] Muriithi, N.G., Gitari, W.M., Petrik, F.L., Ndung'u, P.G. (2011) Carbonation of brine impacted coal fly ash: implications for $\mathrm{CO}_{2}$ sequestration. Journal of Environmental Management 92, 655-664.

[11] Muriithi, N.G., Petrik, F.L., Fatoba, O., Gitari, W.M., Doucet, F.J., Nel, J., Nyale, S.M., Chuks, P.E. (2013) Comparison of $\mathrm{CO}_{2}$ capture by ex-situ accelerated carbonation and in in situ naturally weathered coal fly ash. Journal of Environmental Management 127, 212-220.

[12] Muriithi, N.G., Petrik, F.L., Doucet, F.J. (2014) Remediation of industrial brine using coal-combustion fly ash and $\mathrm{CO}_{2}$. Desalination 353, 30-38.

[13] Muriithi, N.G., Petrik, F.L., Doucet, F.J. (2015) Geochemical modelling of brine remediation using accelerated carbonation of fly ash. Desalination and Water Treatment, 1-11, DOI: 10.1080/19443994.2014.1003607.

[14] Musyoka, N.M., Petrik, L.F., Hums, E., Baser, H., Schwieger, W. (2014) In situ ultrasonic diagnostic of zeolite X crystallization with novel (hierarchical) morphology from coal fly ash. Ultrasonics 54, 537-543.

[15] van der Merwe, E.M., Mathebula, C.L., Prinsloo, L.C. (2014a) Characterization of the surface and physical properties of South African coal fly ash modified by sodium lauryl sulphate (SLS) for applications in PVC composites. Powder Technology 266, 70-78.

[16] Böke, N., Birch, G.D., Nyale, S.M., Petrik, L.F. (2015) New synthesis method for the production of coal fly ash-based foamed geopolymers. Construction and Building Materials 75, 189-199.

[17] Matjie, R.H., Bunt, J.H., van Heerden, J.H.P. (2005) Extraction of alumina from coal fly ash generated from a selected low rank bituminous South African coal. Minerals Engineering 18, 299-310.

[18] Shemi, A., Mpana, R.N., Ndlovu, S., van Dyk, L.D., Sibanda, V., Seepe, L. (2012) Alternative techniques for extracting alumina from coal ash. Minerals Engineering 34, 30-37.

[19] Shemi, A., Ndlovu, S., Sibanda, V., van Dyk, L.D. (2015) Extraction of alumina from coal fly ash using an acid leach-sinter-acid leach technique. Hydrometallurgy 157, 348-355.

[20] Highfield, J., Lim, H., Fagerlund, J., Zevenhoven, R. (2012) Activation of serpentine for $\mathrm{CO}_{2}$ mineralization by flux extraction of soluble magnesium salts using ammonium sulfate. RSC Advances 2 , 6535-6541. 
[21] Bayer, G., Kahr, G., Mueller-Vonmoos, M. (1982) Reactions of ammonium sulphates with kaolinite and other silicate and oxide minerals. Clay Minerals 17, 271-283.

[22] Nagaishi, T., Ishiyama, S., Matsumoto, M., Yoshinaga, S. (1984) Reactions between ammonium sulphate and metal oxides (metal $=\mathrm{Cr}, \mathrm{Mn}$ and $\mathrm{Fe}$ ) and thermal decomposition of the products. Journal of Thermal Analysis 29, 121-129.

[23] Abd-Elzaher, M.M. (1999) Investigation of the reaction of roasted serpentine ore with some ammonium salts. Journal of the Chinese Chemical Society 46, 975-982.

[24] Mudher, K.D.S., Keskar, M., Venugopal, V. (1999) Solid state reactions of $\mathrm{CeO}_{2}, \mathrm{ThO}_{2}$ and $\mathrm{PuO}_{2}$ with ammonium sulphate. Journal of Nuclear Materials 265, 146-153.

[25] Nduagu, E., Björklöf, T., Fagerlund, J., Wärnå, J., Geerlings, H., Zevenhoven, R. (2012) Production of magnesium hydroxide from magnesium silicate for the purpose of $\mathrm{CO}_{2}$ mineralisation. Part 1 . Application to Finnish serpentinite. Minerals Engineering 30, 75-86.

[26] Mohamed, S., van der Merwe, E.M., Altermann, W., Doucet, F.J. (2016) Process development for elemental recovery from PGM tailings by thermochemical treatment: Preliminary major element extraction studies using ammonium sulphate as extracting agent. Waste Management 50, 334-345.

[27] Li, L.S., Liao, X.Q., Wu, Y.S., Liu, Y.Y. (2012) Extracting alumina from coal fly ash with ammonium sulfate sintering process. Proceedings of TSM $142^{\text {nd }}$ Annual Meeting \& Exhibition, Orlando, FL, 215-217.

[28] Wang, P., Li, L., Wei, D. (2014) Kinetics analysis on mixing calcination process of fly ash and ammonium sulfate. Chinese Journal of Chemical Engineering 22, 1027-1032.

[29] Wu, Y., Xu, P., Chen, J., Li, L., Li, M. (2014) Effect of temperature on phase and alumina extraction efficiency of the product from sintering coal fly ash with ammonium sulfate. Chinese Journal of Chemical Engineering 22, 1363-1367.

[30] van der Merwe, E.M., Prinsloo, L.C., Mathebula, C.L., Swart, H.C., Coetsee, E., Doucet, F.J. (2014b) Surface and bulk characterization of an ultrafine South African coal fly ash with reference to polymer applications. Applied Surface Science 317, 73-83.

[31] Jambor, J.L., Pertsev, N.N., Roberts, A.C. (1995) New mineral names. American Mineralogist 80, 845850. 
[32] Shimobayashi, N., Ohnishi, M., Miura, H. (2011) Ammonium sulphate minerals from Mikasa, Hokkaido, Japan: boussingaultite, godovikovite, efremovite and tschermigite. Journal of Mineralogical and Petrological Sciences 106, 158-163.

[33] Niu, X., Chen, J. (2014) Morphology, crystal structure and hydration of calcined and modified anhydrite. International Journal of Minerals, Metallurgy and Materials 21, 1028-1032.

[34] Izquierdo, M., Querol, X. (2012) Leaching behaviour of elements from coal combustion fly ash: An overview. International Journal of Coal Geology 94, 54-66.

[35] Romão, I., Gando-Ferreira, L.M., Zevenhoven, R. (2015) Separation and recovery of valuable metals extracted from serpentinite during the production of $\mathrm{Mg}(\mathrm{OH})_{2}$ for $\mathrm{CO}_{2}$ sequestration. Minerals Engineering 77, 25-33.

[36] Romão, I., Gando-Ferreira, L.M., Zevenhoven, R. (2013) Combined extraction of metals and production of $\mathrm{Mg}(\mathrm{OH})_{2}$ for $\mathrm{CO}_{2}$ sequestration from nickel mine ore and overburden. Minerals Engineering 53, 167-170.

[37] Nduagu, E., Highfield, J., Chen, J., Zevenhoven, R. (2014) Mechanisms of serpentine-ammonium sulphate reactions: towards higher efficiencies in flux recovery and $\mathrm{Mg}$ extraction for $\mathrm{CO}_{2}$ mineral sequestration. RSC Advances 4, 64494-64505. 